\title{
Life Support
}

National Cancer Institute

\section{Source}

National Cancer Institute. Life Support. NCI Thesaurus. Code C95171.

Any medical procedure used to sustain the life of a patient in critical condition. 